This item was submitted to Loughborough's Research Repository by the author.

Items in Figshare are protected by copyright, with all rights reserved, unless otherwise indicated.

\title{
E-readers and the death of the book: or, new media and the myth of the disappearing medium
}

PLEASE CITE THE PUBLISHED VERSION

http://dx.doi.org/10.1177/1461444815586984

PUBLISHER

(c) Sage

VERSION

AM (Accepted Manuscript)

\section{PUBLISHER STATEMENT}

This work is made available according to the conditions of the Creative Commons Attribution-NonCommercialNoDerivatives 4.0 International (CC BY-NC-ND 4.0) licence. Full details of this licence are available at: https://creativecommons.org/licenses/by-nc-nd/4.0/

\section{LICENCE}

CC BY-NC-ND 4.0

\section{REPOSITORY RECORD}

Ballatore, Andrea, and Simone Natale. 2019. "E-readers and the Death of the Book: Or, New Media and the Myth of the Disappearing Medium". figshare. https://hdl.handle.net/2134/19497. 
Suggested Citation:

Ballatore, A. \& Natale, S. E-Readers and the Death of the Book: or, New Media and the Myth of the Disappearing Medium. New Media \& Society. Published online ahead of print May 18, 2015, doi: $10.1177 / 1461444815586984$.

\title{
E-Readers and the Death of the Book: \\ or, New Media and the Myth of the Disappearing Medium
}

Andrea Ballatore, University of California Santa Barbara

Simone Natale, Humboldt University Berlin

Accepted version, final version available at:

http://nms.sagepub.com/content/early/2015/05/18/1461444815586984.abstract

\begin{abstract}
The recent emergence of e-readers and e-books has brought the death of the book to the centre of current debates on new media. In this article, we analyse alternative narratives that surround the possibility of the disappearance of print books, dominated by fetishism, fears about the end of humanism, and ideas of techno-fundamentalist progress. We argue that, in order to comprehend such narratives, we need to inscribe them in the broader history of media. The emergence of new media, in fact, has often been accompanied by narratives about the possible disappearance of older media: the introduction of television, for instance, inspired claims about the forthcoming
\end{abstract}


death of film and radio. As a recurrent narrative shaping the reception of media innovation, the myth of the disappearing medium helps us to make sense of the transformations that media change provokes in our everyday life.

\section{Introduction}

In The Future of Book, a collection of essays published in 1996, editor Geoffrey Nunberg noted that prophecies of a future where printed books had been superseded by electronic media often dominated the public discussion on the future of this medium. Despite his scepticism about the accuracy of these predictions, Nurnberg could not resist the temptation of formulating another prophecy himself: "by the end of the decade," he wrote, "all our current talk of the "end of the book' will sound as dated and quaint as most of the other forecasts of this type" (Nunberg, 1996: $13)$.

More than fifteen years later, prophecies about the end of the book are far from disappearing. Although it is now a given that people can read effectively on the screen as well as on paper (Stoop et al., 2013), the recent commercial success of e-readers gave new credit to the idea that books were going to "die" in debates about the role and the influence of digital media. When e-reading devices from different companies started to flood consumer markets in the 2000s, the end of the print book became again a common trope in journalistic commentaries that reflected on the impact of new technologies on the act of reading. Also in the academic field, while most authors tend to argue that e-books will likely coexist with print books rather than substitute them, many continue to refer to predictions about the end of the book as a rhetorical starting point to introduce their counterargument (e.g. Sica, 2011). 
This article aims to discuss these predictions and to frame them in the broader context of the history and theory of media. If we look more broadly at the history of media, in fact, we discover that, even before the advent of digital media, prophecies about the possible disappearance of an old medium as a consequence of the introduction of a new one have often shaped debates about technology, innovation, and their impact on society and culture. We will therefore address the following question: what does the recurrence of this prophecy tell us about media and, most of all, about how they are perceived, experienced, and imagined? The reason of the persistence of this myth, we argue, lies in its narrative structure: it is a striking tale about the transformative power of technology, easy to remember and to spread. Particularly in the case of media such as books, which are omnipresent as material objects in everyday life, media change may be perceived as something that calls into question established habits and patterns of interaction with the environment. One of the strategies we employ in order to make sense of such changes is the use of narrative patterns that are available and familiar, such as narratives of death and ending. The myth of the disappearing medium has been so influential in this context because it provides a familiar narrative to domesticate the transformations stimulated by the emergence of new media. It reminds us of the extent to which media change is perceived as the harbinger of innovation as well as loss, as a creative but at the same time destructive process. More broadly, it serves as an encouragement to media historians to reflect on the close links between the ways media histories are constructed and the inner dynamics of narration and storytelling.

Erkki Huhtamo proposes that the aim of media archaeology, a branch of media history of which he is one of the leading figures, should be to study "recurring cyclical phenomena that (re)appear and disappear and reappear over and over again in media history, somehow seeming to transcend specific historical contexts" (Huhtamo, 1997: 222). Huhtamo called these recurring 
phenomena topoi, borrowing a term that goes back to the classical rhetorical tradition, where they referred to prefabricated formulae, which could be employed in the composition of orations. Our examination of the myth of the death of the book and, more generally, of the disappearing medium relies on a similar approach. The recurrence of these prophecies allows us to employ media history as a means to better comprehend present configurations and, conversely, to use the case of digital media to learn something about how media change is perceived and represented (see Park et al., 2011). As Kermode (2000) points out, the invocations of such apocalyptic discontinuities can be regarded as expressions of a fictional paradigm deployed to find coherent patterns in the flow of change.

This paper is divided into two parts. In the first part, we will examine how the idea that the book is dying has shaped the debate on the introduction of digital technologies, particularly of e-books and e-readers. In the second part, we will discuss the myth of the disappearing medium, according to which a new medium is perceived as a menace for older ones, as a topos that often characterizes the reception of new media in the public sphere. As we will show, this myth conceals a particular vision of media change.

\section{E-readers and the death of the book}

The emergence of e-books and e-readers did not follow a trajectory of incremental success, but rather a series of faltering starts and uneasy acceptances. The development of the actual idea of the electronic book (e-book) is principally attributed to Andries Van Dam, who coined the term working on a hypertext system in 1967, and Michael Hart, who founded Project Gutenberg in 1971. Despite the promise of a new age of virtual libraries, for two decades e-books were 
constrained to large, desktop-based machines, which substantially limited their adoption and appeal. The development of e-readers, therefore, responded to the need for portable devices that could facilitate the reading of e-books. Unlike tablet PCs, which are presented as generalpurpose devices, e-readers use technical innovations such as the e-ink screen to mimic the appearance and features of print books, enabling new forms of distribution and consumption of long texts.

The first wave of the commercialisation of e-readers started in the late 1990s, to end abruptly in the 2001 dot-com bubble burst. During this period, e-readers did not succeed in finding broad commercial applications and were generally dismissed as a failed technology, or, as a human-computer interaction expert simply put it, as "a bad idea" (Nielsen, 1998). This state of affairs was subject to a radical transformation in the late 2000 s, when a second wave of ereaders was launched. In a phase of rapid commercial expansion, these enhanced e-readers, such as the Sony Reader and the Amazon Kindle, gained prominence in the consumer market. As a result of these changes in production and consumption patterns, the print book is seen at the crossroad between declining revenues for publishers, disaggregation of content across online platforms, shortening attention span, explosion of fragmented reading habits, disappearance of physical bookstores, and loss of committed readers. Although it is not possible to quantify the predicaments of the book purely in economic terms, it is uncontroversial that print-based business models and practices are experiencing a radical and at times painful re-configuration (Murray and Squires, 2013).

In the 1990s, in a digital media landscape dominated by the growing World Wide Web and bulky, desktop-based computers, the debate on the mortality of print books revolved around the alleged superiority of the hypertext and its non-linearity, rather than directly on the physical 
properties of paper. The resolution of computer screens was deemed too low to be even comparable to paper, and e-ink was considered only as a promising but yet unrealized possibility (Nunberg, 1996). In contrast, the commercial success of e-reader technologies in the late 2000s moved the discussion from the textual organisation of the text to a focus on the delivery technology. If the codex is not going to die, the print book might be the next sacrificial victim of digital media.

Well in the 2010s, it is apparent that paper has not disappeared and that hypertext is far from having killed the codex as a cultural form. In what York (2006) calls the "Paperless Office Paradox," digital media have occasionally raised demand for paper, rather than leading to its disappearance. Web-based hypertexts have proven very successful in specific contexts, such as general reference (e.g. Wikipedia), journalism (newspaper websites tend to host highly interlinked short texts), and technical manuals. However, the linearity of the codex has not been abandoned, and has been only marginally enriched by hypertextuality. E-books can contain hyperlinks, but they are used primarily in footnotes or references, not in the body of the text. Furthermore, the codex and its linearity have showed considerable resilience in the face of the cluttered, overloaded realm of the Web, offering a reassuring refuge. Long, linear texts are not only still produced, but digital media have enabled a boom of self-publishing and low-cost distribution of novels in the U.S. (Bowker, 2012). The disintermediation of the publishing process enables a plethora of new modes of publications, such as fan fiction and collaborative authorship (Soules, 2009).

While paper and the codex are usually not perceived to be in peril in their individual forms, concerns have frequently focused on the health of their combination, the printed book. Prophecies about the end of the book are mainly articulated around two narratives: print books 
are endangered and their death could have catastrophic consequences (Section 1.1); print books will be inexorably killed by digital media, and this event will have liberating effects (Section 1.2). A third narrative, according to which print books will not die, and will co-exist with digital media, with mixed and unclear effects (Section 1.3), has emerged, countering prophecies on the end of the book (see Table 1). As a closer examination of each of them shows, the anxiety surrounding the possible death of book was deployed as a metaphorical device to frame discussions on the impact of digital media on cultural, social and economic practices.

\begin{tabular}{|c|c|c|c|}
\hline & $\begin{array}{c}\text { Narrative } 1 \\
\text { (end of humanism) }\end{array}$ & $\begin{array}{c}\text { Narrative } 2 \\
\text { (digital utopia) }\end{array}$ & $\begin{array}{l}\text { Narrative } 3 \\
\text { (coexistence) }\end{array}$ \\
\hline $\begin{array}{l}\text { Print book, } \\
\text { codex, paper }\end{array}$ & $\begin{array}{l}\text { Repository of civic and } \\
\text { humanist values. Deep } \\
\text { reading, sensorial } \\
\text { experience. Superseded } \\
\text { by digital media (and } \\
\text { should not be). }\end{array}$ & $\begin{array}{l}\text { Outdated medium to } \\
\text { store and retrieve text. } \\
\text { Superseded by digital } \\
\text { media (and should be). }\end{array}$ & $\begin{array}{l}\text { Resilient medium that is } \\
\text { not likely to be } \\
\text { superseded by the other } \\
\text { two media. }\end{array}$ \\
\hline $\begin{array}{l}\text { PC, hypertext, } \\
\text { screen (1980s- } \\
1990 \text { s) }\end{array}$ & $\begin{array}{l}\text { Loss of humanist values, } \\
\text { superficial reading } \\
\text { habits. Dominance of } \\
\text { hypertext. Loss of } \\
\text { sensorial dimension. }\end{array}$ & $\begin{array}{l}\text { Revolution of } \\
\text { communications, } \\
\text { hypertext as intrinsically } \\
\text { superior to codex, } \\
\text { liberation of information. }\end{array}$ & $\begin{array}{l}\text { Co-existence with print } \\
\text { books. Hypertext not } \\
\text { suitable in many } \\
\text { contexts. }\end{array}$ \\
\hline $\begin{array}{l}\text { E-reader, e-book, } \\
\text { e-ink (2000s, }\end{array}$ & $\begin{array}{l}\text { Loss of senses, damage } \\
\text { to publishing industry. }\end{array}$ & $\begin{array}{l}\text { Increased access to long } \\
\text { texts, long tail economy }\end{array}$ & $\begin{array}{l}\text { Co-existence with print } \\
\text { books. Suitable for }\end{array}$ \\
\hline
\end{tabular}




\begin{tabular}{|l|l|l|l|}
\hline 2010s) & $\begin{array}{l}\text { Status of the print book } \\
\text { diminished. }\end{array}$ & for books. & $\begin{array}{l}\text { linear reading of fiction, } \\
\text { less so for study/work } \\
\text { on long texts. }\end{array}$ \\
\hline
\end{tabular}

Table 1: Narratives about the future of the book

1.1 The death of the book as the end of humanism

Because education in the humanities traditionally relies on print books, neo-luddites associate the virtues of critical appraisal of classics with the medium on which such activity is generally performed, the print book. As digital computers displace print books from their pedestal, essayist Sven Bikerts (1994: 6) wrote in his nostalgic elegy that "literature offers a kind of wisdom that cannot be discovered elsewhere; ... the bound book is the ideal vehicle for the written word." In this technologically deterministic narrative, the emergence of digital media, in particular in their hypertextual form, causes a loss of values and, ultimately, humanity. Philosopher of technology Albert Borgmann (1984) advanced carefully pessimistic arguments on the societal effects of digital technologies. From a complementary perspective, Dreyfus (2008) critiqued the promise of the Web for education, stressing the embodied nature of reading and learning. In this respect, Thierer (2011) provides a comprehensive review of "techno-pessimists" who lament negative cultural effects of the Web, including Neil Postman, Todd Gitlin, Mark Helprin, Maggie Jackson, and Andrew Keen.

In recent years, concerns about the apparent impossibility of "deep reading" on computers have been discussed, suggesting a McLuhanesque anthropological change, induced by the interaction with short texts online versus long texts on paper (Carr, 2010). J.P. de Tonnac describes the loss of printed pages as something affecting a "certain sense of sacred that has 
surrounded the book in a civilization that has made it our holy of holies" (Carrière and Eco, 2011: vii). The elegy of dying books evokes sensorial properties that are perceived as being central to the medium, and physical features of the print book have gained an unprecedented centrality in the social and cultural space (MacFadyen, 2011). As e-readers manage to effectively imitate the visual properties of paper, readers are giving more importance to touch and smell when handling print books, with detectably nostalgic undertones. Nostalgia for print books is inscribed in a general sense of, as Turner put it, "a historical decline and loss, involving a departure from some golden age of "homefulness"” (Turner, 1987: 150). Often considered a "lower sense", smell is a fundamental trigger to nostalgic phenomena (Hirsch, 2006).

The naturalisation of books underpins this narrative. Although print books are technological artefacts produced within a complex socio-technical apparatus, they are perceived as more "natural" and permanent than e-readers (e.g. Basbanes, 2003). Even if both print books and e-readers are obviously machines_-"machines to think with", as Richards (2001: vii) defined books - the "naturality" of print books is reinforced by the properties of paper. Unlike the plastic and silicon of electronic devices, paper is an organic matter, decays, developing unique smellsoften very unpleasant, as noted by artist Rachael Morrison (2011). Different types of paper develop different smells and trigger different tactile responses. Moreover, print books, especially cheap ones, "remember" the reader's passage by altering their physical structure, whilst e-readers are seen as impersonal, static, and doomed to obsolescence in unstable technological markets.

Although e-readers mimic them in many respects, books still attract praise for their versatility. As late as 2009, Eco re-stated as an argument in favour of print books that computers "cannot be read in a bath, or even lying on your side in bed" (Carrière and Eco, 2011: 4). Annie Proulx stated that "nobody is going to sit down and read a novel on a twitchy little screen. Ever" 
(qtd. in O'Donnell, 1996: 37). Ray Bradbury, who actively tried to prevent the publication of his works as e-books, stated that e-readers 'aren't books. You can't hold a computer in your hand like you can a book. A computer does not smell" (Weller, 2010). What he perceived as the future death of print books was something that Bradbury actively fought, until his death in 2012.

\subsection{Liberating the book from its mortal coil}

The second narrative hinges on the death of print books from an opposite perspective: instead of being praised as sacred repositories of wisdom, print books are seen as an obsolete medium that will be inexorably replaced by a more efficient digital device, with predominantly positive consequences. In this narrative, it is possible to find echoes of more radical critiques of the print book and its structure, particularly in relation to its perceived authority. In 1909, the Italian Futurist Filippo Tommaso Marinetti invited his followers to burn down libraries (Marinetti, 2006: 14). Also, as part of the Student-Writer Action committee in 1968, Maurice Blanchot envisaged the overthrow of the book, which "held knowledge prisoner" (Carrière and Eco, 2011: 261). More recently, Gomez stated that "pages are cages, trapping the words within boundaries" (2008: 14), seemingly oblivious of the dominance that the page exerts on digital media.

These provocations can be seen as rooted in the hypertextual imagination inaugurated by Bush (1945: 57) and his early vision of the Memex. The liberating potential of the hypertext has been celebrated by a diverse array of technologists and thinkers, starting from Ted Nelson's claim that "[o]pen hypertext publishing is the manifest destiny of free society" (Nelson, 1992: 57). This strand of what Turner (2006) dubbed "digital utopianism" was championed by Stuart Brand, Kevin Kelly, and Nicholas Negroponte-who stated in 2010 that print books will be "dead 
in five years" (Siegler, 2010). From a complementary viewpoint, the decentralized information sharing enabled by the web attracted praise from scholars Yochai Benkler (2006) and Clay Shirky (2008)—writing from a libertarian perspective, Thierer (2011) surveyed such notable "techno-optimists" systematically. In media forecasts, Duguid (1996) identified two recurring themes. On the one hand, new media aim at the supersession of existing media, in post-modern radical breaks with the "burden of the past." On the other, liberationism interprets the development of digital media as a triumphant march of a free-market-oriented idea of progress. Starting from the often-quoted idea that "information wants to be free" (Brand qtd. in Turner, 2006: 136), liberationists praise the increased access to texts and the virtues of the immateriality of virtual text.

Technologists of such ideological leanings forecast the death of the book as a hope rather than a fear, revealing the influence of two main claims about the passage from pre-digital to digital technologies. First, the success of a new medium can be assessed by its power of displacement and disruption in the media landscape. A highly successful medium kills old media in a logic of supersession (Duguid, 1996), and the inevitable and positive nature of this disruption is the core belief of digital utopianism. Second, the death of old media should not be mourned as a loss of cultural values and sedimented social meanings, but should be embraced precisely as evidence of technological progress. Whoever clings to old media should be disposed of along with the medium-notably, Mitchell (1995: 56) referred to bibliophiles as people "addicted to the look and feel of tree-flakes encased in dead cow." A medium that causes only a slight repositioning in the media landscape is not truly innovative. A new medium creates a new culture, and unleashes latent market forces in a process of Schumpeterian creative destruction. 
Bold predictions about the death of books might well be, as O’Donnell (1996) put it, a "mug's game," but they constitute a crucial communication device, deployed very often in mainstream media. Technologists of this inclination tend to fall in what has been called "technofundamentalism" (Vaidhyanathan, 2011), the optimistic belief that problems are best solved through technological solutions. Digital utopianists also tend to overlook limitations of e-readers that make the supersession of print books unlikely.

Since the 1980s, a growing body of research in psychology, human-computer interaction, and library and information science has studied the differences between reading on paper and on screen (MacFadyen, 2011; Holt, 2011). According to Jabr (2013), this growing multidisciplinary literature does not show a clear consensus, but rather depicts a complex, rapidly evolving picture. The printed medium shows specific cognitive advantages for deep reading and active learning, mainly for its physical spatial organization that facilitates exploration and reinforces retention, although the actual difference in outcomes is often small or negligible (e.g. Rockinson-Szapkiw et al., 2013). Like volumina, e-readers favour an extremely linear mode of reading, making non-linear access to long texts clumsy and slow. Whilst they are generally perceived as suitable for linear, leisure reading, they are often regarded as less adequate for the deep, non-linear reading practiced by students and scholars in an academic setting.

\subsection{The coexistence of e-books and print books}

As the previous two narratives of the death of the book are rightly deemed to be untenable, a third option emerges. This narrative firmly rejects the possibility of the death of books, emphasising the patterns of coexistence that are likely to arise. As e-readers become ubiquitous and their presence has proved to accompany rather than to substitute paper books, numerous 
academic and journalistic writers have increasingly followed this approach. This has resulted in shifting the debate towards a more nuanced consideration of what the "end" of the book may really mean. Recent academic discussions tend to abandon the idea that the print book will completely disappear, to focus on issues such as the rise of new forms of interaction with texts (MacWilliam, 2013), shortening attention spans (Hassoun, 2014), changes in the publishing industry and the distribution chain (Murray and Squires, 2013), or the unrestrained dominance of new private actors such as Google (Darnton, 2009). In parallel, evidence shows that students still prefer to study on print books (e.g. Stoop et al., 2013), although the rising adoption of tablets and e-readers, coupled with the increased availability of digital textbooks, might impact this trend.

In the current context, a new understanding of the book as a social and cultural form is emerging, stressing the book's function as a means of communication over its material form (Weedon et al., 2014). The print or electronic quality of the book is regarded as secondary to its role as a vehicle of information and as a cultural form. The debate on the future of the book has been increasingly shifting from the logic of supersession towards a more nuanced approach that interrogates how writers, readers, and the publishing industry react to the ongoing transformations, and how these agents are contributing to reshape both print and digital forms of publications. In his passionate advocacy for libraries, book historian Robert Darnton (2009) firmly positions himself in the coexistence strand, arguing that, unlike the fragile and rapidly changing digital tools, print books are still the most effective medium to store and share information long-term. The history of media shows substantial continuities, and Darnton believes that digital media will not entirely displace paper books. Similarly, "manuscript publishing flourished long after Gutenberg's invention" (xiv). 
Despite its cogency, however, the narrative of coexistence has not yet resulted in a complete dismissal of the prophecies about the end of the book. ${ }^{1}$ For example, the Institute for the Future of the Book alludes to this anxiety in its very name. As the think-tank's mission states, "the printed page is giving way to the networked screen. The Institute for the Future of the Book seeks to chronicle this shift, and impact its development in a positive direction" (p. na). ${ }^{2}$ Similarly, over the past five years, an impressive number of popular publications have mentioned the death of the book in their title. ${ }^{3}$

\section{The Disappearing Medium: Interrogating a Recurrent Myth}

As we have showed, forecasts of the possible disappearance of books have strongly shaped public discourse following the recent commercial success of e-readers. Such predictions, however, are not an isolated case in the history of media technologies. The emergence of a new medium, in fact, often stimulates prophecies and forecasts about the disappearance of older media. The introduction of television, for instance, aroused claims about the possible end of cinema and radio; today, the development of digital media inspires predictions about the end of television (Natale and Ballatore, 2014). In order to fully comprehend contemporary preoccupations about the death of book, and to understand how these inform the perception and use of the new technology of e-readers, it is thus necessary to frame it in media history and theory. This may also mean interrogating how such preoccupations are embedded in particular visions of how media change throughout time, and how they influence our societies and our relationship to technology.

Despite the recurrence of prophecies about the possible disappearance of media, the existence of a pattern that connects the emergence of a new medium with the disappearance of an 
older one does is not confirmed by historical insight. As scholars such as De Sola Pool et al. (1977) and Nye (2004) have shown, technological prophecies have often been wrong, especially when they were conceived by commentators and not by inventors or early developers of the technologies to which they referred. Predictions about the disappearance of media are not an exception: old media frequently do not disappear, but react in complex ways to the introduction of new ones, modifying their commercial applications and institutional frames, or targeting different audiences or publics (Balbi, 2005). Cinema, for instance, did not die following the introduction of television, although this was widely perceived as a menace and resulted in strong changes in the film industry. Nor did television "kill" radio or newspapers, as was feared by many (Stephens, 1998).

Why does the introduction of a new medium so frequently suggest that older media should die? One of the reasons is, as Patrice Flichy notes, that "all too often the inventors of new communication systems reason in terms of substitution, when they would do better thinking along the lines of shifts of uses and technologies" (Flichy, 1995: 173). While it might often seem intuitive that a new medium will substitute an older one, usages might differentiate much more than is expected, opening new fields of application for "old" media. In this sense, the idea that a medium would die often reveals a narrowly technical vision of media: "specific delivery technologies (the eight-track cassette, say, or the wax cylinder) may become moribund, but the medium of recorded sound survives" (Thorburn and Jenkins, 2003: 2).

The tendency to underestimate the flexibility of usages, however, only partially explains the recurrence of the myth of the disappearing medium in media history. In what follows, we propose that what made this myth so persistent and influential lies is its narrative nature, and the way it converts cultural discourses on the power of technology into a tale that is easily 
remembered and can be told again and again. Employing the notion of "biographies of media" to describe how media change is the subject of narration and storytelling, we argue that the myth of the disappearing medium helps us to make sense of the transformations of our everyday life kindled by media change.

\subsection{Narratives of Media Change: Unveiling the Biographies of Media}

As Alan Liu perceptively notes, the introduction of new media is channelled symbolically through the emergence and diffusion of particular narratives, which he calls "narratives of media encounter." These tales, he points out, are instrumental in shaping the sociocultural reception of the ongoing change, making it more easily understood and transmitted (Liu, 2007). In this regard, literary theories on storytelling and biographical writing are useful to comprehend how such narratives proliferate and become meaningful in the history of media. James Olney famously equated biographical writings to "metaphors of the self," stressing how they provide ways to understand new experiences by creating a connection with an experience already incorporated in our mindset. Likewise, narratives of new media encounters are metaphors providing "something known and of our making, or at least at our choosing, that we put stand for, and so to help us understand, something unknown and not of our making" (Olney, 1972: 30).

It is important to stress that our aim is not to argue that the history of a medium is similar to the lifetime of an individual. We would like, instead, to point out that the way media histories are related and recounted follows narrative patterns that are similar to those used to relate the story of a person's life. Indeed, as proposed elsewhere (Natale, forthcoming), media, like people, are the subject of biographical writing: their biographies, or in other words the ways their history is the subject of narration and storytelling, contribute to shape their identities and to carry 
particular representations of their roles in our society and everyday life. As Reeves and Nass (1996) have aptly shown, when people interact with computers, televisions and new media, they often follow some of the same social rules that lead their interaction with humans. A similar "media equation"-to employ the term proposed by Reeves and Nass-characterizes in many cases the use of narratives to describe media change throughout time, too. Similarly to how in the biographies of notable people anecdotes and narrative tropes enforce claims about their personality and broader notions related to their profession and agency (Kris and Kurz, 1979; Ortoleva, 1996), "biographies of media" play a paramount role in determining how media are represented and imagined within the public sphere. Unveiling recurring narratives that emerge repeatedly and in different moments of media history helps therefore to gain new insights into how media change is represented and imagined. It helps to make sense of how media are entangled in particular narratives, and how these narratives influence their presence and reception in the public sphere.

Not only with regard to the history of media, but also in other contexts, scholars have noted that recurring narrative patterns often reveal the presence of particular cultural assumptions. To return to the comparison with biographical writings, such patterns often carry specific assumptions of the character and agency of notable individuals. In biographies of artists, for instance, recurring narrative patterns bring about certain claims about the nature of artistic creation, or the existence of an "artistic" temperament (Kris and Kurz, 1979); in biographies of inventors, they shape the cultural imagination about the act of invention and the process of innovation (Ortoleva, 1996). In a similar way, narrative patterns such as the disappearance of old media participate in the construction of "biographic accounts" of media, shaping how new and old technologies are represented and imagined within the public sphere. As Helen Fulton (2005: 
7) rightly observes, it is by employing existing narrative patterns that one structures and makes sense of new experiences and events. The myth of the disappearing medium, in this sense, employs a fictional trope that is deeply engrained in Western culture: the idea that each epoch is characterized by the end of what came before, and the beginning of something new (Kermode, 2000). Providing a familiar narrative to domesticate the transformations stimulated by the emergence of new media, it helps "to make sense, give comfort" (44) in ages of media change.

\subsection{Innovation, Loss, and Everyday Life}

But why has this specific narrative recurred so often in the history of media? What does the narrative of the disappearing medium tell us about the ways we imagine and make sense of media change? As Mark Weiser put it, "the most profound technologies are those that disappear," those that "weave themselves into the fabric of everyday life until they are indistinguishable from it" (Weiser, 1991: 94). As a result, when a new medium is perceived as the potential substitution for an old one, reactions of emotional affection and nostalgia emerge. In media history, many examples of similar reactions can be found. The shift from silent to sound movie, for instance, stimulated a feeling of nostalgia for the older form. The same happened in the shift from analogue to digital photography and film (Marks, 1997), or from black and white to color television (Barnouw, 1990).

The feeling of nostalgia is particularly strong in cases such as the book, in which the old medium is also a material object (Appadurai, 1986; Attfield, 2000) that can be conserved, collected, and be the subject of emotional attachment (Miller, 2008). This explains, also, why the narrative of the disappearing medium has been particularly relevant in the reception of innovations in fields such as sound recording: since the origins of this technology, in fact, the act 
of listening has always been accompanied by the desire to collect and by a sometimes fetishistic attachment to records as material objects (Gitelman, 2006: 25-57). In periods of technological transition, this might result in the feeling, perceived by many, that new formats, like digital compact discs, are less "authentic" than older ones, such as the vinyl record (Davis, 2007).

Discussing contemporary reactions to the introduction of e-books and e-readers, Ted Striphas notes how these innovations have put into question habits and expectations that characterize our everyday life. He observes that the everyday is what can be counted on, something that provides the necessary stability to manage our experience and our social life; books, in this context, are perceived as "everyday entitlements" (Striphas, 2009: 11), i.e. objects that help manage such stability and shape expectations in everyday life. It is also because they jeopardize our perception of everyday life, he speculates, that e-books "appear to some as harbinger of loss of knowledge, authority, history, artistry, and meaning" (22).

In order to theoretically frame similar reactions, it is useful to refer to the concept of the aura in Walter Benjamin. Benjamin developed the concept of the aura particularly in his essay The Work of Art in the Age of Mechanical Reproduction (1968), where he argued that film and other technologies of technical reproduction diminished the aura that belonged to earlier, irreproducible works of arts. Recently, Jay David Bolter and his collaborators have proposed a particular interpretation of Benjamin's notion, arguing for the possibility of employing it in reference to digital technologies. According to their view, the aura should be regarded as a changing concept, which does not only concern the shift from uniqueness to reproducibility following the introduction of photography and film, but also the reception of other new media forms in different times. The introduction of reproducible media such as photography and film should therefore be regarded as one episode in a more general crisis of the aura, which is 
replicated today in the reactions stimulated in the public by the digital turn. This crisis is connected to the capacity of media technologies to generate an aura, convincing the user "that she is in the presence of the authentic" (Bolter et al., 2006: 29). In this sense, the notion of the aura could be employed to explain reactions of nostalgia kindled by the experience of loss of everyday certainties or "entitlements" (Striphas, 2009: 11) such as books. Contemporary reactions to the introduction of digital technologies, which point to their diminished authenticity and to nostalgia for older media, can thus be read as the revived emergence of worries about a loss of the aura and authenticity in novel media forms. Indeed, as Vivian Sobchack has shown, feelings of nostalgia are evoked by virtually all technological turns -even when these are limited to changes in computer software (Sobchack, 1999).

The idea that the experience of reading on a digital device lacks authenticity/aura is also corroborated by some recent surveys on the reception of e-readers (Shin, 2011: 266). It is important, moreover, to note that issues such as the smell of the binding and the feel of paper started to play a more significant role when e-reader and e-book technologies began to be perceived as a menace to the old paper book. Before that, neither the mainstream literary culture, nor the academic culture of the 19th and 20th centuries showed much interest in these material qualities (Rindisbacher, 1992). Paradoxically, the smell of paper becomes meaningful only to the extent that this is perceived as something that might disappear. A similar dynamic can be observed also in other cases in the history of media: with the passage from vinyl to digital music recording, for instance, the former has increasingly been regarded as a cult object and an item for collecting (Davis, 2007). This might suggest that elements connected to the materiality of old media gain additional relevance in moments of crisis of the aura. As a consequence, something that could well be understood as a minor change in the media form of the book, such as the 
material shift from printed books to e-books, acquires particular emphasis in a moment of technological change. After all, as Striphas recalls, the everyday is "kind of like trusted friends, who are there for us day in and day out. It's as though they've always been a part of our lives, and the meaningfulness and stability they provide may not fully register until they're gone" (Striphas, 2009: 10).

The interpretation of the idea of the aura as connected to a perceived loss of authenticity in new media is particularly relevant to our discourse if we recall Flichy's call to consider the social use of a given technology -and with it, its insertion into everyday life- as being not less meaningful than issues of technique and standard (Flichy, 1995: 173). In order to explain predictions about disappearing media, it is of crucial importance to understand how media enter into the existence of people, how they build emotional bonds and how they are treated as an integral part of one's life (Appadurai, 1986). The sense that new media such as e-readers bring with them a deficit of authenticity or "aura" in Bolter et al.'s terms, in this sense, is revealing of a perception of media change as a process in which innovation is inseparable from loss. As we have attempted to show, this perception is deeply engrained in the narrative of the end of the book and in recurring narratives about the disappearance of other media.

\section{Conclusion}

Addressing the complex spectrum of imaginary constructions connected to hype about digital media, Vincent Mosco used the word myth to label those stories "that animate individuals and societies by providing paths to transcendence that lift people out of the banality of everyday life" (Mosco, 2004: 3). Such stories do not necessarily need to be false: what is relevant, instead, is 
their capacity to resonate in the culture of their age. As Mosco observes, in fact, myths "are not true or false, but living or dead" (2004: 3).

Predictions about the disappearance of books are, in this regard, myths in Mosco's sense. In order to understand their significance for the reception and the acceptance of new reading technologies, we need to go beyond the question whether they are false or true. It is, after all, difficult if not impossible to predict how e-readers and e-books will evolve in the future, and whether the book will blend with other, non-linear media towards new forms of digital storytelling. Books might eventually disappear in the future: in fact, the very nature of predictions as hypothetical claims makes it impossible-or forcefully speculative-to consider them either true or false (Natale, 2014). Such prophecies, however, are revealing of the way societies regard media as vehicles for change - precisely because they are embedded in the idea of the future. The debate on the death of the book we have examined, therefore, can tell us much about how media change and the digital turn are perceived and represented within the public sphere. As we have argued, this debate should be seen as the manifestation of a particular vision of the effects on our society and on our lives brought about by new digital media.

Excavating the roots of this media myth provides us with a better understanding of how new media are perceived as elements of innovation, but also as the carriers, to a certain extent, of loss and deprivation. Such a representation of media change is paramount in discussions between those who see the e-reader as a threat for the book, and those who deny this might ever occur. Either one might be wrong, but both are revealing of some of the deepest concerns aroused by the emergence of digital media, as well as by other new media in history. The "death" of the book, as a medium and an object that has become such an important part of our life and of the 
world as we know it, might in fact be quite easily mistaken for a sign of the inescapability of our own end.

\section{Works Cited}

Appadurai A. (1986) The social life of things: Commodities in cultural perspective, Cambridge: Cambridge University Press.

Attfield J. (2000) Wild things: The material culture of everyday life, Oxford: Berg.

Balbi G. (2005) I vecchi e i giovani: Strategie di mimesi tra old e new media. Studies in Communication Sciences 5: 183-204.

Barnouw E. (1990) Tube of plenty: The evolution of American television, New York: Oxford University Press.

Basbanes NA. (2003) A splendor of letters: The permanence of books in an impermanent world, New York: HarperCollins.

Benjamin W. (1968) The work of art in the age of mechanical reproduction. Illuminations. New York: Schocken Books, 217-251.

Benkler Y. (2006) The wealth of networks: How social production transforms markets and freedom, New Haven, Conn.: Yale University Press.

Birkerts S. (1994) The Gutenberg elegies: The fate of reading in an electronic age, Boston, Mass.: Faber and Faber. 
Bolter JD, MacIntyre B, Gandy M, et al. (2006) New media and the permanent crisis of aura. Convergence: The International Journal of Research into New Media Technologies 12: 21-39.

Borgmann A. (1984) Technology and the character of contemporary life: A philosophical inquiry, Chicago: University of Chicago Press.

Bowker. (2012) Self-publishing in the United States, 2006-2011: Print vs. ebook. Report published by Bowker.

Bush V. (1945) As we may think. The Atlantic Monthly 176: 101-108.

Carr NG. (2010) The shallows: What the Internet is doing to our brains, New York: W.W. Norton.

Carrière J-C and Eco U. (2011) This is not the end of the book: A conversation curated by JeanPhillippe De Tonnac, London: Harvill Secker.

Darnton R. (2009) The case for books: Past, present, and future, New York, NY: PublicAffairs.

Davis J. (2007) Going analog: Vinylphiles and the consumption of the "obsolete" vinyl record. In: Acland CR (ed) Residual media. Minneapolis: University of Minnesora Press, 222236.

De Sola Pool I, Dekker C, Dizard S, et al. (1977) Foresight and hindsight: The case of the telephone. In: De Sola Pool I (ed) Social impact of the telephone. Cambridge, MA: MIT Press, 127-157.

Dreyfus HL. (2008) On the internet, London: Routledge.

Duguid P. (1996) Material matters: The past and the futurology of the book. In: Nunberg G (ed) The Future of the Book. Berkeley: University of California Press, 63-102. 
Flichy P. (1995) Dynamics of modern communication: The shaping and impact of new communication technologies, London: Sage Publications.

Fulton H. (2005) Narrative and media, Cambridge: Cambridge University Press.

Gitelman L. (2006) Always already new: Media, history and the data of culture, Cambridge, Mass.: MIT Press.

Gomez J. (2008) Print is dead: Books in our digital age, London: Macmillan.

Hassoun D. (2014) "All over the place": A case study of classroom multitasking and attentional performance. New Media \& Society. Epub ahead of print April 14, 2014. Doi: $10.1177 / 1461444814531756$

Hirsch AR. (2006) Nostalgia, the odors of childhood and society. In: Drobnick J (ed) The smell culture reader. Oxford: Berg, 187-189.

Holt GE. (2011) Change happens: Book selling, libraries, and e-readers. Public Library Quarterly 30: 185-190.

Huhtamo E. (1997) From kaleidoscomaniac to cybernerd: Notes toward an archaeology of the media. Leonardo 30: 221-224.

Jabr F. (2013) The reading brain in the digital age: The science of paper versus screens. Scientific American. Available at: http://www.scientificamerican.com/article/reading-paper-screens (accessed 15 April 2015)

Kermode F. (2000) The sense of an ending: Studies in the theory of fiction, Oxford: Oxford University Press.

Kris E and Kurz O. (1979) Legend, myth, and magic in the image of the artist: A historical experiment, New Haven: Yale University Press. 
Liu A. (2007) Imagining the new media encounter. In: Siemens RG and Schreibman S (eds) A companion to digital literary studies. Malden, MA: Blackwell Pub., 3-25.

MacFadyen H. (2011) The reader's devices: The affordances of ebook readers. Dalhousie Journal of Interdisciplinary Management 7: 1-15.

MacWilliam A. (2013) The engaged reader. Publishing Research Quarterly 29: 1-11.

Marinetti FT. (2006) Critical writings, New York: Farrar, Straus, and Giroux.

Marks LU. (1997) Loving a disappearing image. Cinémas 8: 93-111.

Miller D. (2008) The comfort of things, Cambridge, UK: Polity.

Mitchell WJ. (1995) City of bits: Space, place, and the infobahn, Cambridge, Mass.: MIT Press.

Morrison R. (2011) Smelling the books. Inside/Out, A MoMA Blog. Available at: http://www.moma.org/explore/inside_out/2011/03/07/smelling-the-books (accessed 15 April 2015)

Mosco V. (2004) The digital sublime: Myth, power, and cyberspace, Cambridge, Mass.: MIT Press.

Murray PR and Squires C. (2013) The digital publishing communications circuit. Book 2.0 3: 323.

Natale S. (2014) Introduction: New media and the imagination of the future. Wi: Journal of Mobile Media 8: 1-8.

Natale S. (forthcoming) Unveiling the biographies of media: On the role of narratives, anecdotes and storytelling in the construction of new media's histories.

Natale S and Ballatore A. (2014) The Web will kill them all: New media, digital utopia, and political struggle in the Italian 5-Star Movement. Media, Culture \& Society 36: 105-121. 
Nelson TH. (1992) Opening hypertext: A memoir. In: Tuman MC (ed) Literacy online : the promise (and peril) of reading and writing with computers. Pittsburgh: University of Pittsburgh Press, 43-57.

Nielsen J. (1998) Electronic books - A bad idea. Jakob Nielsen's Alertbox. Available at: https://www.nngroup.com/articles/electronic-books-a-bad-idea (accessed 15 April 2015)

Nunberg G. ed. (1996) The Future of the book, Berkeley: University of California Press.

Nye DE. (2004) Technological prediction: A Promethean problem. In: Sturken M, Thomas D and Ball-Rokeach S (eds) Technological visions: The hopes and fears that shape new technologies. Philadelphia: Temple University Press, 159-176.

O'Donnell JJ. (1996) The pragmatics of the new: Trithemius, McLuhan, Cassiodorus. In: Nunberg G (ed) The future of the book. Berkeley: University of California Press, 37-62.

Olney J. (1972) Metaphors of self: The meaning of autobiography, Princeton, N.J.: Princeton University Press.

Ortoleva P. (1996) Vite geniali: Sulle biografie aneddotiche degli inventori. Intersezioni 1: 4161.

Park DW, Jankowski N and Jones S. ed. (2011) The long history of new media: Technology, historiography, and contextualizing newness, New York: Peter Lang.

Reeves B and Nass CI. (1996) The media equation: How people treat computers, television, and new media like real people and places, Stanford, Calif.: CSLI Publications.

Richards IA. (2001) Principles of literary criticism, London: Routledge.

Rindisbacher HJ. (1992) The smell of books: A cultural-historical study of olfactory perception in literature, Ann Arbor: University of Michigan Press. 
Rockinson-Szapkiw AJ, Courduff J, Carter K, et al. (2013) Electronic versus traditional print textbooks: A comparison study on the influence of university students' learning. Computers \& Education 63: 259-266.

Shin D-H. (2011) Understanding e-book users: Uses and gratification expectancy model. New Media \& Society 13: 260-278.

Shirky C. (2008) Here comes everybody: The power of organizing without organizations, New York: Penguin Press.

Sica A. (2011) To the Barricades!! Save the Printed (Scholarly) Book!! Contemporary Sociology: A Journal of Reviews 40: 659-661.

Siegler MG. (2010) Nicholas Negroponte: The physical book is dead in 5 years. Tech Crunch. Available at: http://techcrunch.com/2010/08/06/physical-book-dead (accessed 15 April 2015)

Sobchack V. (1999) Nostalgia for a digital object: Regrets on the quickening of QuickTime. Millennium Film Journal 34: 4-23.

Soules A. (2009) The shifting landscape of e-books. New Library World 110: 7-21.

Stephens M. (1998) "Which communications revolution is it, anyway?". Journalism \& Mass Communication Quarterly 75: 9-13.

Stoop J, Kreutzer P and Kircz J. (2013) Reading and learning from screens versus print: a study in changing habits. New Library World 114: 284-300.

Striphas TG. (2009) The late age of print: Everyday book culture from consumerism to control, New York: Columbia University Press. 
Thierer AD. (2011) The case for Internet optimism, Part 1-saving the Net from its detractors. In: Szoka B and Marcus A (eds) The next digital decade: Essays on the future of the Internet. Washington, DC: TechFreedom, 57-91.

Thorburn D and Jenkins H. (2003) Rethinking media change: The aesthetics of transition, Cambridge: MIT Press.

Turner BS. (1987) A note on nostalgia. Theory, Culture \& Society 4: 147-156.

Turner F. (2006) From counterculture to cyberculture: Stewart Brand, the Whole Earth Network, and the rise of digital utopianism, Chicago: University of Chicago Press.

Vaidhyanathan S. (2011) The Googlization of everything (and why we should worry), Berkeley: University of California Press.

Weedon A, Miller D, Franco CP, et al. (2014) Crossing media boundaries: Adaptations and new media forms of the book. Convergence: The International Journal of Research into New Media Technologies 20: 108-124.

Weiser M. (1991) The computer for the twenty-first century. Scientific American 265: 94-100.

Weller S. (2010) Ray Bradbury, the art of fiction No. 203: Interviewed by Sam Weller. The Paris Review. Available at: http://www.theparisreview.org/interviews/6012/the-art-of-fictionno-203-ray-bradbury (accessed 15 April 2015)

York R. (2006) Ecological paradoxes: William Stanley Jevons and the paperless office. Human Ecology Review 13: 143-147. 


\section{Endnotes}

${ }^{1}$ A quantitative hint on the surge of public interest in the death of the book from the 1970 s can be observed in the Google N Gram Viewer: http://goo.gl/4eJOxk, accessed on October 28, 2014.

${ }^{2}$ http://futureofthebook.org/mission.html, accessed on October 28, 2014.

${ }^{3}$ Other examples of titles include: “Caterwauling over death of books is premature," "How eBooks Will Lead To The Disappearance of Books," and "The Death of the Book, Again." 